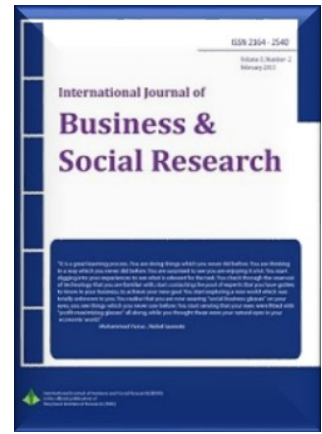

\title{
Role of Corporate Social Responsibility Practices in Saudi Universities
}

\author{
Bandar Khalaf Alharthey ${ }^{1}$
}

\begin{abstract}
Nowadays, many researchers focus on the relocation of the government in the transformation of The purpose of this study is to examine the role of Corporate Social Responsibility (CSR) practices in higher education of Saudi Arabia. The growing importance of CSR has made it necessary for every university to use international benchmarks as standard to devise their CSR practices accordingly. This realization has shifted focus of CSR practices of Saudi universities towards every dimension of CSR. The study collected secondary data through 120 advertisements published from 2012 to 2015 and found out that CSR practices of universities of Saudi Arabia remain focused on social dimension of CSR because Saudi culture and religion had profound impact on business laws and eventually on CSR practices.
\end{abstract}

Keywords: Corporate social responsibility, economic dimension, environmental dimension, social dimension. Available Online: 21-02-2016

This is an open access article under Creative Commons Attribution 4.0 License, 2016.

\subsection{INTRODUCTION}

Corporate Social Responsibility (CSR) is a concept that adds to the brand and good will of the institution and the stakeholders that are related to it (Jamali, 2012). Whether, that institution is a business institution or a non-profit one, the brand and good will matters immensely to the core existence and survival of the institution and that where Corporate Social Responsibility really come into play and carries a significant role. For this reason, many enterprises and institutions around the world are investing heavily into CSR departments to ensure their survival and promotion of their brand and activities.

The concept of CSR is not new and novel and goes back to the times of famous Greek philosophers like Plato, Aristotle, Kant, Marx, and many others. The only new thing that many institutions are still not aware of how to function their CSR departments and add the 'social dimension' to their business. Here

\footnotetext{
${ }^{1}$ Department of Business Administration, Arab East Colleges, Riyadh, Kingdom of Saudi Arabia. Mobile: +966559099279 E-mail: bkalharthey@arabeast.edu.sa
} 
are some comprehensive and up to date definitions of CSR. The World Business Council for Sustainable Development defines CSR as follows:

"Corporate Social Responsibility is the continuing commitment by business to behave ethically and contribute to economic development while improving the quality of life of the workforce and their families as well as of the local community and society at large. The same report gave some evidence of the different perceptions of what this should mean from a number of different societies across the world."

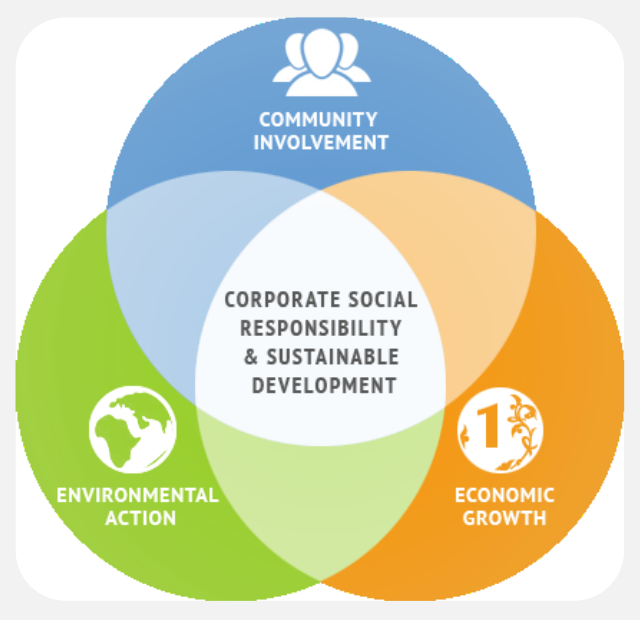

The growing importance of CSR functions in the societal development is being recognized all over the world. However, in Saudi Arabia this function of the corporation remain focused on philanthropic efforts most of the time, which is largely driven and influenced by its social, religious and cultural aspects of the country. Moreover, government had not forced or pushed corporations to introduce CSR programs beneficial for the society, which is why it remain largely focused on philanthropic efforts. In relation to the above discussion, this study aims to analyze the role of CSR in higher education in Saudi Arabia.

\section{DIMENSIONS OF CSR}

There are 3 core dimensions that are mainly focused in CSR policies and strategies of the company which includes: social, economic and environmental dimension.

\section{SOCIAL DIMENSION}

All ethical and philanthropic activities carried out by the institution add to the social dimension of the CSR. Ethical aspects include fair policies for both business employees and customers or end users of the product or service whereas philanthropic ones are concerned with social charities and playing an active role to support or oppose a social cause (Fleming, 2012). An example of social responsibility is when an educational institution launches an awareness program for the general public by means of seminars and workshops via which the institution's brand also gets promoted and the society also gets the benefit as well.

\section{ENVIRONMENTAL DIMENSION}

Environmental sustainability initiatives enacted by businesses generally focus on two main areas: limiting pollution and reducing greenhouse gases. As the awareness of environmental issues grows, businesses that take steps to reduce air, land and water pollution can increase their standing as good corporate 
citizens while also benefiting society as a whole. An example of environmental responsibility is when an educational institution adopts a policy of recycling wastes and scrap. This policy will not just save the costs of the institution but also keeps the environment clean and healthy for everyone.

\section{ECONOMIC DIMENSION}

Economic responsibility focuses on practices that facilitate the long-term growth of the business, while also meeting the standards set for ethical, environmental and philanthropic practices. By balancing economic decisions with their overall effects on society, businesses can improve their operations while also engaging in sustainable practices. As an example, when an educational institution adopts a policy of recycling wastes and scrap. This policy will not just save the costs of the institution but also keeps the environment clean and healthy for everyone.

\subsection{CONCEPT, ROLE AND FUNCTIONS OF CSR}

CSR is an aspect that has been the core topic of many executive discussions nowadays and recent times as well. There have been differing perspectives on CSR (Smith, 2013). Some experts argued that CSR is achieved as long as an institution does goes against the law while others are of the opinion that the institution has a duty to ensure a "good society" and has to return to the society or community in which it operates. According to the United Nations Industrial Development Organization the common corporate social responsibility functions include: responsible sourcing of materials and supplies; employee, vendor, customer and community engagement and relations; adherence to labor and industry standards; environmental protection and management; anti-corruption actions and measures; upholding social equity, gender equity and other human rights goals; conservation of resources, like water and energy, in production; and monitoring of purpose and benefits of corporate social responsibility.

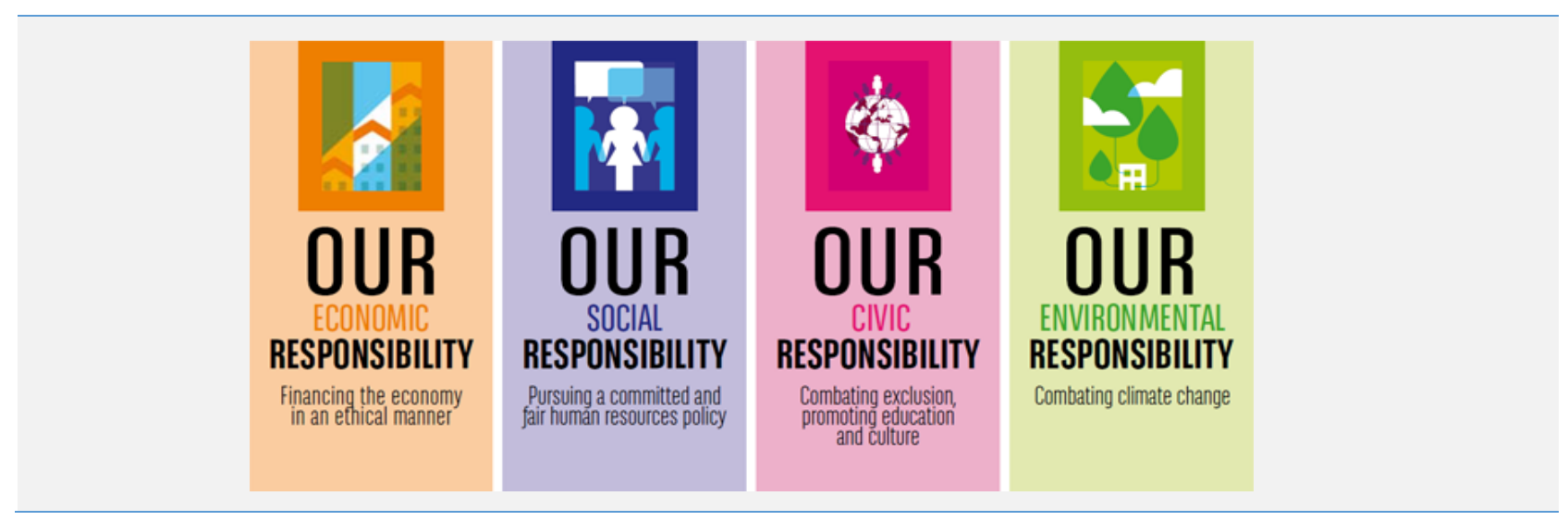

\section{IMPORTANCE OF CORPORATE SOCIAL RESPONSIBILITY FOR SOCIETY AND BUSINESS}

In recent years, environmental issues have flooded the businesses and demonstrated the ability to create value for customers, shareholders and other stakeholders. The forces of globalization have led companies to incorporate social and environmental dimension in management. Today, companies want to associate their brands to projects, initiatives and partnerships with NGOs, disclose the Millennium Development Goals in order to demonstrate corporate social responsibility. On the other hand, managers receive an avalanche of information, trivializing the practices and social responsibility policies and management processes. It appears that the concerns with corporations are more directed to show that they are socially responsible and sustainable than integrating the environmental dimension in business. And yet it is assumed that sustainable refers to both environmental and social aspects, and that sustainability is a new business model, more modern than social responsibility (Ioannou \& Serafeim, 2014).

There is confusion over the definition of sustainability. Korschun, Bhattacharya \& Swain (2014) state that avoid using the word sustainability or use it as little as possible, because it is such a generic term that 
people perceive as a standard of achievement. The idea of sustainability or sustainable development began largely to environmental concerns, which turned out to involve the economic and social dimensions and, from the 1990s, now includes corporate social responsibility. The evolution of the social responsibility concept is different. Its origin is in the ethical issues surrounding the relationship between business and society and corporate philanthropy.

The theoretical concept of social responsibility originated in the 1950s, when the formal literature on corporate social responsibility appears in the United States and Europe. The concern of the Kilkenny (2014) was that decade with excessive autonomy of the business and their power in society without proper responsibility had produced negative impacts of their activities on societies, such as environmental degradation, exploitation of labor, economic abuse and unfair competition. To offset the negative impacts of the activities of businesses, entrepreneurs engaged in social activities to benefit the community, outside the scope of the companies' business, as a moral obligation.

Corporate philanthropy has emerged as a new field of activity which has gained increasing visibility in Saudi Arabia. However, the expression corporate philanthropy is associated with historical references as charity, paternalism and welfare, which have a negative connotation, because it does not bring effective social and economic transformation for the development of communities. Today, when considering about corporate social responsibility; it is noted consensus on the requirement that this investment should occurs as a company policy, not only as a personal commitment of the entrepreneur. Therefore, companies sought alternative terms for their own actions in this field, such as social investment, corporate social action, social participation or community enterprise or social development (Juscius \& Snieska, 2015).

One of the major issues that are raised in relation to social and environmental issues is whether these affect the competitiveness of enterprises. According to the classical view of the company, incorporating social and environmental issues beyond the legal requirement increases costs and reduces corporate profits. The debate on the content and extent of social responsibility in business was intense, to counteract the economic social and environmental performance.

The role of business include profits, but instead of maximizing short-term profit, business should seek long-term profits, obey the laws and regulations regarding the non-marketing impact of their decisions and look for ways to improve society by a targeted operation to accountability and sustainability of business. The concept of sustainable development is now fully integrated into the concept of social responsibility: there will be no economic growth in the long term without social progress and also without environmental care. All sides should be viewed and treated with equal weight and not only because these are interrelated aspects. Just as economic growth is not sustainable without a social and environmental equivalence, social and environmental corporate programs will not stand if there is no economic balance of the company.

\subsection{METHODOLOGY}

It is important to select the appropriate method for research in order to drive meaningful, credible, reliable and valid results. Selection of appropriate research method is vital for overall research and thus should be selected with caution and after analyzing every aspect of the nature of the study. Analysis of the nature of the study would help in using appropriate method, which in turn would help in producing meaningful results. Since, the aim of this study is to analyze the role and trends of CSR practices of the Saudi universities in promoting and enhancing higher education, this study has used qualitative technique and collected the data required for this research using secondary method of data collection. Secondary data refers to already collected or published data and covers data from already published research, journals, books, magazine, periodicals, encyclopedia, blog, websites, government organizations among others. Secondary data for this research have been collected through 120 advertisements published from 2012 to 2015. 


\subsection{DISCUSSION AND ANALYSIS}

The data collected from 120 advertisements published from 2012 to 2015 related to CSR practices of Saudi universities. The analysis of the data has revealed that $72 \%$ of CSR practices are covering the side of social approach; $17 \%$ of CSR practices covering the side of economic approach; and 11\% of CSR practices are covering the side of environmental approach. The fact indicates that Saudi universities do not fully understand the concept of CSR or failed to realize its importance to overall business and society.

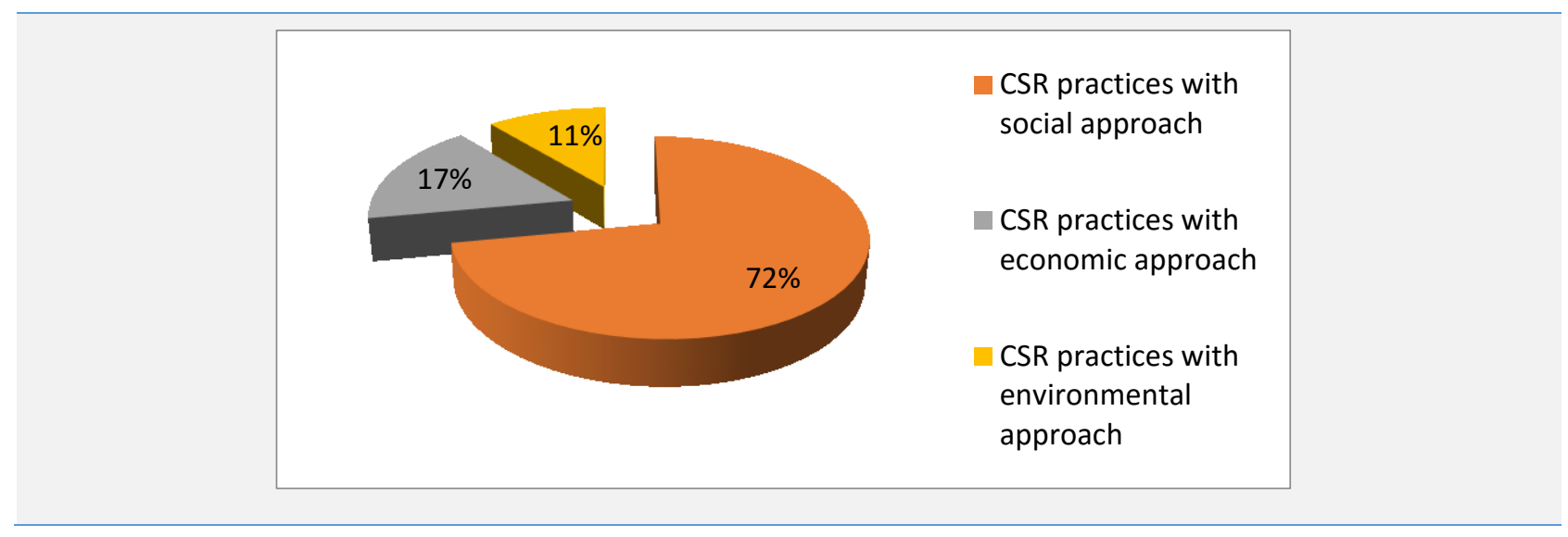

In Saudi Arabia increasing focus is being given to the subject that local and international companies should invest their CSR budget in the projects related to education and development. Corporations are realizing the roles they could play to develop projects promoting higher education in the country, which is good for both future workforce development and demonstrating their affection towards the society. CSR's popularity in Saudi Arabia is growing, but in the country driven by strict religious laws and cultural values, the projects of CSR are required to be tailor made for the country which should promote its religious, social and cultural values (CSR Saudi Arabia, 2014). CSR normally do not offer any financial benefits of the business, but the increasing understanding of the overall concept that made business realize that it adds value in the bottom line. According to Gravem (2010), companies now find it more useful and necessary to show to the customers, stakeholders and to the society that they follow responsible business practices which would also help in strengthening the corporate reputation of the company.

One study related to CSR awareness found out that in Saudi Arabia the concept of CSR is not really clear to many local and foreign companies as well as to the community and for many years CSR in the country has been restricted to community engagement and philanthropic efforts of corporation. However, according to CSR Saudi Arabia, (2014) many companies operating in the country had now using international benchmark and therefore introducing strategic approaches with increasing focus on addressing economic and social challenges faced by the community. CSR now in Saudi Arabia is not just a limited concept as universities now consider it as a method for enhancing their competiveness, which would ultimately help in the development of the country.

The top focus areas for the companies as per the international benchmark include promotion education, youth development, employment and gender diversity. The firms have realized that education is the most important sector and should be center of their CSR approach, as the outcomes of investing in this sector under normal circumstances reflects on society, business, entrepreneurship and youth among others - all these aspects mentioned are important for the overall societal benefits in the long-run. According to Ali \& Al-Aali (2012), the higher education system of the Kingdom is not well established, which is highly important for the country to proper and grow in every aspect including environmental, political, social and economic. Allocation of CSR budget in projects related to higher education is important which in turn should be beneficial for the development of youth. It is noted in the study by Ali \& Al-Aali (2012) that the young population in Saudi Arabia is increasing and should be regarded as a valuable asset for the country. However, limited and ineffective educational and extra-curricular 
opportunities have restricted the engagement of youth in societal development. Moreover, according to the report of CSR Saudi Arabia (2014) if CSR and the government both failed to fill the gap of higher education would develop an unemployment burden on the people of the country, and as the oil prices are going down combined with huge allocations of financial reserves on development of infrastructure it is evident that if this gap is not filled the company would have to face harsh economic conditions. In CSR Saudi Arabia, an event to discuss the current and future projects of the companies operating in the region, it has been identified that higher education should be given priority over other projects as this approach is truly needed and demonstrate the responsible behaviors of the company. At the event it has been identified by Mohammad Abdulaziz Al-Ohali, deputy minister of higher education that around 181 CSR projects related to higher education has been proposed, and the ministry has approved 52 of them. These 52 projects are presently being implemented in 13 Saudi universities (Jiffry, 2014).

\section{TOP FOCUS AREAS}

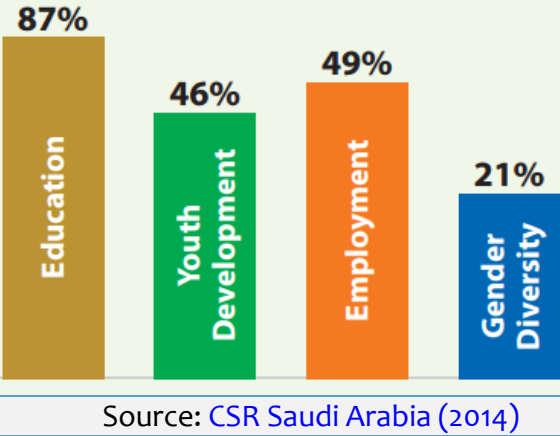

Higher education projects is not a small and simple category to address, and therefore, need is to initiate purposeful CSR based higher education projects which focuses more on developing skills that would be useful for the individuals, society and the country, rather than implementing programs that actually serve no purpose. Higher education programs cover everything from teaching theory and practices to skill development and guidance. SEDCO Holding, a Saudi Arabia based private company for wealth management, conducted a survey in 2006 and identified that Saudi youth getting higher education have no basic understanding of financial concepts like budgeting, investment and saving. Thus, the company initiated a program following its CSR practices to help educate the youth of the country about the basic financial information so as to upon graduation they have adequate knowledge of the financial concepts and can better manage their overall finances. The program for financial literacy launched by the company was called Riyali, in which US based international nonprofit organization "Operation Hope" and Ministry of Labor of Saudi Arabia were also stakeholders and partners. The need of the program was also justified with the fact that without basic financial knowledge young people would face variety of financial difficulties in their lives ahead as well as in their professional career. Moreover, the company also aims with this program to develop skilled and capable workforce (Shehadi and Jamjoom, 2014).

Another company of Saudi Arabia Abdul Latif Jameel Group provides the perfect example of how higher education is at the centre of CSR projects and strategy. In 2003 the company initiated a project Abdul Latif Jameel Community Initiatives (ALJCI), according to which the CSR policies of the company would introduce projects for higher education aiming to create jobs. The focus of its many programs lies in identification of job opportunities and providing training and skills to students for the creation of new businesses. The CSR program of the company according to estimates has created over 100,000 jobs in Saudi Arabia and other MENA countries (Shehadi and Jamjoom, 2014).

Similarly, various organizations are focusing their CSR efforts towards enhancement of higher education as to develop youth, increase entrepreneurship and trained them for career and personal life. For example, Emirates Integrated Telecommunications Company (also known as du) had initiated a question and answer online platform, which aims to help people or aspiring entrepreneurs to ask questions related to business problems and their questions were answered by the experts from the field (Shehadi and 
Jamjoom, 2014). However, some other companies operating in the Kingdom are more concerned with projects that offer guidance, mentorship, training and skills in various fields aiming to enhance the higher education.

\subsection{CONCLUSION}

From the above discussion, it can be concluded that despite government's efforts and will; need for higher education for Saudi people are not realized as it should have been. On the other hand, universities as part of their CSR strategy remain more focused on philanthropic approach due to religious and social factors of the country. This has restricted the corporations to remain focus on social dimension of the CSR aspect rather than expanding the scope of their projects on economic and environment dimension. The data collected also indicate that until recently the focus of the CSR policies of many local and international corporations remain focused on social dimension. It is also revealed in the discussion that Saudi universities do not fully understand the concept of CSR, which has been attributed as the main reason for the focus of their policies on social dimension. The discussion has also identified that companies has now realized the need for expanding the scope of their projects to higher education as to meet the future social, economic and environmental needs of the company and have been initiating projects accordingly. The projects aiming towards improving and enhancing the higher education should help not only society but also help businesses in establishing a good corporate reputation while developing skilled, trained and qualified workforce.

\section{REFERENCES}

Aarts, P. (2005). Saudi Arabia in the balance: Political economy, society, foreign affairs. Washington Square, NY: New York Univ. Press.

Ali, A. J., \& Al-Aali, A. (2012). Corporate social responsibility in Saudi Arabia. Middle East Policy, 19(4), 4053.

Cordesman, A. H. (2003). Saudi Arabia enters the twenty-first century: The political, foreign policy, economic, and energy dimensions. Westport, Conn: Praeger.

Crane, A. (2013). Corporate social responsibility: Readings and cases in a global context. London [u.a.: Routledge.

CSR Saudi Arabia. (2014). Top CSR Trends in Saudi Arabia. [Online] lirme.com, retrieved on: October 29, 2015 from: http://assets.iirme.com/sites/iirme.com/Conferences/BM/csrsaudi/Resources/AZ3048CSR_Saudi_Report.pdf

Fleming, P., \& Jones, M. T. (2012). The end of corporate social responsibility. London: Sage.

Gravem, O. M. B. (2010). Corporate Social Responsibility in Saudi Arabia. [Online] retrieved on: October 29, 2015 from: https://www.duo.uio.no/handle/10852/32802

Ioannou, I., \& Serafeim, G. (2014). The impact of corporate social responsibility on investment recommendations: Analysts' perceptions and shifting institutional logics. Strategic Management Journal.

Jamali, D.\&Sidani, Y. (2012). CSR in the Middle East: Fresh perspectives. Houndmills, Basingstoke, Hampshire: Palgrave Macmillan.

Jiffry, F. (2014). Corporations must invest in education. [Online] ArabNews.com, retrieved on: October 29, 2015 from: http://www.arabnews.com/news/665011

Juscius, V., \& Snieska, V. (2015). Influence of corporate social responsibility on competitive abilities of corporations. Engineering Economics, 58(3).

Kilkenny, S. (2014). Corporate Social Responsibility. Network Journal, 21(3), 24.

Korschun, D., Bhattacharya, C. B., \& Swain, S. D. (2014). Corporate social responsibility, customer orientation, and the job performance of frontline employees. Journal of Marketing, 78(3), 20-37.

Lee, N., \& Kotler, P. (2013). Corporate social responsibility: Doing the most good for your company and your cause. Hoboken, N.J: Wiley. 
Mullerat, R., \& Brennan, D. (2011). Corporate social responsibility: The corporate governance of the 21st century. Alphen aan den Rijn: Kluwer Law International.

Ramady, M. A. (2010). The Saudi Arabian economy. New York: Springer.

Shehadi, R., and Jamjoom, M. (2014).Corporate Social Responsibility's New Role in the Middle East. [Online] Strategy-Business.com, retrieved on: October 29, 2015 from: http://www.strategybusiness.com/article/00234?gko=b365d

Smith, L., \& Abū, A. A.-R. M. (2013). Higher education in Saudi Arabia: Achievements, challenges and opportunities. Dordrecht: Springer. 